\title{
18F-FDG Positron Emission Tomography/Computed Tomography in the Diagnosis and Post-Therapeutic Treatment in a Patient with an Early Stage of Retroperitoneal Fibrosis
}

\author{
Retroperitoneal Fibrozisi Erken Aşamada Olan Bir Hastada Tanı ve Tedavi Sonrası I8F-FDG \\ Pozitron Emisyon Tomografisi / Bilgisayarlı Tomografi
}

\author{
Artor Niccoli Asabella1, A. Nicoletti', C. Altini', A. Notaristefano', G. Lastilla², G. Rubini1 \\ IUniversity of Bari, Nuclear Medicine Unit - Di.M.I.M.P., Bari, Italy \\ 2 University of Bari, Anatomical Pathology Unit 2 - D.A.P.E.G., Bari, Italy
}

\begin{abstract}
Here, we report an experience about 18F-FDG-PET/CT in a patient with an early stage of Idiopathic Retroperitoneal Fibrosis (IRF). At the diagnosis Contrast Enhanced Computed Tomography (CE-CT) revealed periaortic solid tissue in the infrarenal section and locoregional lymph nodes; findings were interpreted as lymphomatous tissue. 18F-FDG-PET/CT showed elevated 18F-FDG uptake in the periaortic tissue but no uptake was detected in lymph nodes. The histologic examination showed recent-onset IRF. The patient began corticosteroid therapy. Nearly at the end of the therapy, CE-CT showed the enlargement of the fibrous tissue and 18F-FDG-PET/CT showed an increased 18F-FDG uptake in the aforesaid lesion and another area of uptake in the aortic wall. 18F-FDG-PET/CT can play an important role in the diagnosis of patients with an initial clinical suspicion of retroperitoneal fibrosis and in their management. Then the patient began a therapy with methotrexate and after six months we performed an 18F-FDG-PET/CT which didn't show 18 F-FDG uptake. Key words: 18 F-FDG positron emission tomography/computed tomography, contrast enhancement computed tomography, idiopathic retroperitoneal fibrosis
\end{abstract}

\section{Özet}

Erken dönemde bir Idyopatik Retroperitoneal Fibrosis (IRF) hastasında yapılan 18F-FDG-PET/BT deneyimini sunduk. Tanı amaçlı Kontrastlı Bilgisayarlı Tomografide (CE-CT) infrarenal bölgede periaortik solid doku ve lokal-bölgesel lenf nodları görüldü ve lenfatik doku olarak yorumlandı. 18F-FDG-PET/BT periaortik dokuda artmış 18 F-FDG tutulumu gösterdi ama lenf nodlarında hiç tutulum yoktu. Histolojik inceleme başlangıç aşamasında IRF olarak geldi. Tedavinin sonuna yakın, CE-CT fibröz dokuda artış ve 18F-FDG-PET/BT önceki bahsedilen lezyonda ve de aort duvarındaki başka bir lezyonda artmış ${ }^{18 F-F D G ~ t u t u l u m u ~ g o ̈ r u ̈ l d u ̈ . ~}{ }^{18 F-F D G-P E T / B T, ~ k l i n i k ~ o l a r a k ~ s ̧ u ̈ p h e l i ~ b u l u n a n ~}$ retroperitoneal fibrosis vakalarının tanı ve yönlendirilmesinde önemli rol oynayabilir. Daha sonra hastaya methotrexate tedavisi başlandı ve altı ay sonra yapılan 18F-FDG-PET/BT de 18F-FDG tutulumu izlenmedi.

Anahtar kelimeler: 18F-FDG pozitron emisyon tomografisi/bilgisayarlı tomografi, kontrast bilgisayarlı tomografi, idiopatik retroperitoneal fibrozis

\section{Introduction}

Idiopathic Retroperitoneal Fibrosis (IRF) is a rare disease (incidence between 40 and 60 years; $M: F=2: 1$ ), defined as a connective-tissue disorder, characterized by the development of fibro-inflammatory tissue in retroperitoneum $(1,2)$.
It is an insidious disease, which could be initially silent, or characterized by non-specific and/or systemic symptoms, sometimes associated with local ones due to the entrapment of retroperitoneal structures. It mostly manifests itself locally through abdominal and back pain $(1,2)$.

Address for Correspondence: Artor Niccoli Asabella MD, University of Bari, Nuclear Medicine Unit - Di.M.I.M.P., Bari, Italy Phone: +39 0805592913 E-mail: a.niccoli@mednucl.uniba.it Received: 27.12.2011 Accepted: 26.11.2012 
Here, we report an experience about 18F-FDG-PositronEmission-Tomography/Computed-Tomography (18F-FDG$\mathrm{PET} / \mathrm{CT}$ ) in the diagnosis and post-therapeutic evaluation in a patient with an early stage of IRF.

\section{Case Report}

A 43-year-old man came at our attention for cramp-like abdominal pain not responding to anti-inflammatory or anti-spastic therapies. Blood and urine tests were normal. One month later a contrast-enhancement computedtomography (CE-CT) revealed the presence of periaortic solid tissue in the infrarenal section (thickness: $14 \mathrm{~mm}$; longitudinal extension: $46 \mathrm{~mm}$; 48-73 HU) and locoregional lymph nodes (Figure 1A).

These findings were interpreted as lymphomatous tissue. One week after CE-CT, blood test showed only increased erythrocyte sedimentation rate (ESR). One month after CE-CT, the patient underwent 18F-FDG-PET/CT in our Nuclear Medicine Unit, which showed elevated 18F-FDG uptake (Figure 1B-1C) in the periaortic tissue surrounding the descending aorta in front of the L3 vertebra (SUV max 4.6); no 18F-FDG uptake was detected in lymph nodes reported at the previous CE-CT (Figure 1B, red circle). After 18F-FDG-PET/CT the patient underwent laparoscopic biopsy; the histologic examination showed the presence of lobular lympho-plasmacellular aggregates and richly vascularized fibrous tissue, corresponding to recent-onset IRF. Then the patient began 9 months of corticosteroid therapy with Prednisone, with pain remission after the first month. After five months of therapy, the patient had a CECT (Figure 1D), which showed a size reduction of the solid tissue (thickness: $4 \mathrm{~mm}$ ).

The inflammatory markers were normal. Nearly at the end of the therapy, corresponding with the lowering of prednisone dose, the patient reported the onset of abdominal pain. For this reason another CE-CT was performed which showed the enlargement of the fibrous tissue (thickness: $8 \mathrm{~mm}$; longitudinal extension: $49 \mathrm{~mm}$, 32-61 HU). A second 18F-FDG-PET/CT showed increased 18 F-FDG uptake, corresponding to the aforesaid lesion
$\left(S_{\text {max }}\right.$ 7.3). Another area of $18 \mathrm{~F}-\mathrm{FDG}$ uptake (Figure 1E$1 \mathrm{~F}$, green arrow) was observed on the right-posterior-lateral aortic wall, at L2 vertebra level (SUV max 5.1). Therefore, according to 18F-FDG-PET/CT findings, clinicians began a new regimen of prednisone and methotrexate (MTX).

After six months we performed an 18F-FDG-PET/CT which didn't show any area of pathological 18F-FDG uptake, confirming the therapy's outcome and then the end of the MTX use (Figure 2).

\section{Literature Review and Discussion}

Macroscopically IRF appears as a fibrous mass, localized between the origin of the renal arteries and the bifurcation of the common iliac at the level of the L4-L5 vertebra (3). Histologically, in the early stages, the tissue is richly vascularized with chronic active inflammation (1, 3); in advanced stages becomes less vascularized and richer in dense collagen fibers $(1,4)$. CE-CT and magnetic resonance are the imaging techniques of choice for diagnosis and

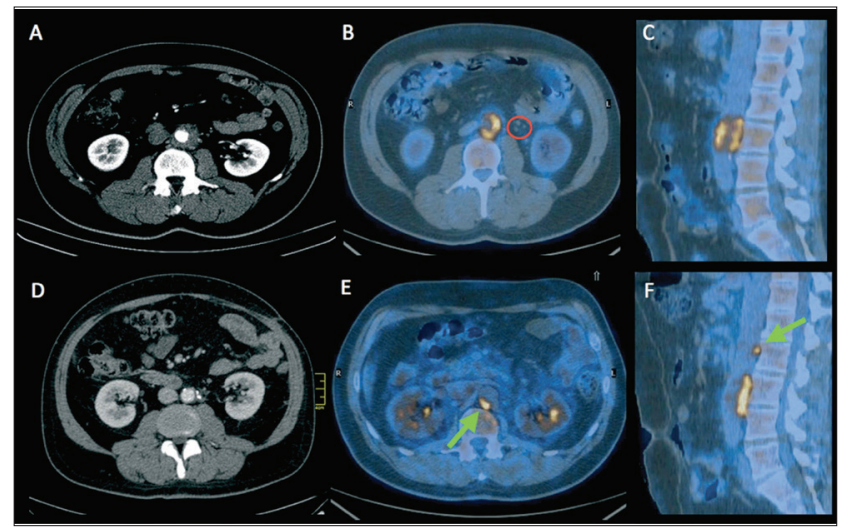

Figure 1. (A) Transaxial CE-CT image performed at diagnosis, showing periaortic solid tissue and locoregional lymph nodes. (B) Transaxial and (C) Sagittal 18F-FDG-PET/CT fused image performed at diagnosis, showing 18F-FDG uptake in the periaortic tissue; no 18F-FDG uptake in lymph nodes reported at CE-CT (red circle). (D) Transaxial CE-CT image performed during corticosteroid therapy, showing size reduction of the solid tissue. (E) Transaxial and (F) sagittal 18F-FDG-PET/CT fused image performed one month after the end of therapy, showing.

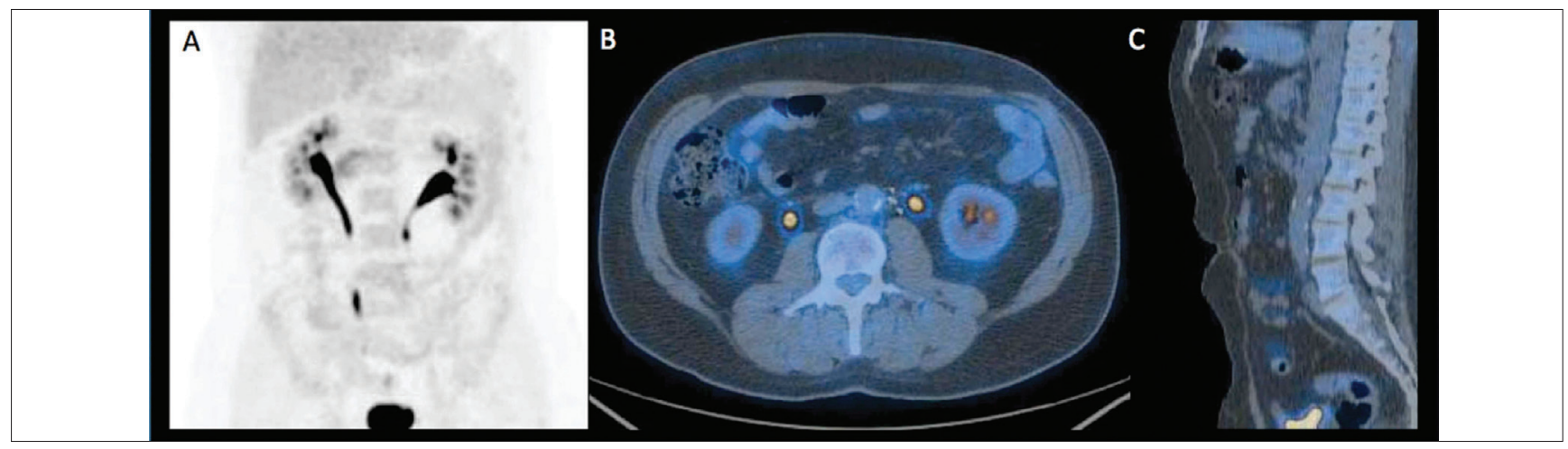

Figure 2. (A) MIP, (B) transaxial and (C) sagittal 18F-FDG-PET/CT fused image performed after 6 months from the beginning of therapy with prednisone and methotrexate which didn't show 18 F-FDG uptake. 
quantification of IRF. CE-CT shows a variable degree of enhancement: intense in the early and acute stages of the disease, minimal in advanced stages. 18F-FDG-PET/CT is used primarily to assess the metabolic activity of the mass. It is useful for identification of aortitis and periaortitis in the acute phase, evaluation of IRF after treatment and in cases of relapse $(5,6)$. The first prospective study in 26 patients evaluated the potential role of 18F-FDG-PET/CT in assessing disease activity. It showed that positive 18F-FDGPET/CT correlates with C-reactive protein (CRP) level and with lesion size. Visual PET score decreased after tamoxifen therapy and correlates with Erythrocyte Sedimentation Rate (ESR) reduction, but not with CT mass regression. The authors concluded that 18F-FDG-PET/CT is valuable in detecting disease activity (presumed IRF or suspected recurrence), particularly in the absence of symptoms and acute phase reactant increase (7).

Definitive diagnosis requires biopsy (8) and histological examination. In medical therapy, steroids play a leading role (9). Methotrexate, azathioprine and mycophenolate are usually reserved for patients who do not benefit from corticosteroid treatments (10). Tamoxifen can also be used, due to its anti-inflammatory and anti-fibrosis action, but corticosteroid therapy is better than tamoxifen in maintenance of remission in patients with idiopathic retroperitoneal fibrosis, and induces a greater shrinkage of the retroperitoneal mass than tamoxifen does (11).

The peculiarity of this case is that our patient showed abdominal pain in an early phase because of the unusual higher location of the disease (at a L3 vertebra level, rich of nerve endings).

In laboratory tests, the most important anomalies that occur are: increased ESR, CRP, the alpha-2-globulin (4). In our patient, CRP values were always within normal range, on the contrary, ESR values were variously amended in agreement with morphological data provided by CE-CT.

18F-FDG-PET/CT led the initial differential diagnosis (lymphoma? Retroperitoneal fibrosis?) documenting the absence of glucose hyper-metabolism in the lymph nodes detected by CE-CT; it ruled out the presence of an extra-peritoneal localization of the disease and identified the most suitable site for biopsy. We did not perform an 18F-FDG-PET/CT during the therapy because the patient was asymptomatic, the inflammatory markers were normal and CE-CT showed lesion size reduction, a clear proof of a good response to therapy. ${ }^{18 F-F D G-P E T / C T ~ i s ~ a b l e ~ t o ~ i d e n t i f y ~}$ with higher sensitivity compared to $\mathrm{CT}$, the persistence of inflammation in the residual tissue after therapy $(12,13)$

In our patient, one month after the end of the therapy, 18F-FDG-PET/CT showed a higher 18F-FDG uptake than the previous 18F-FDG-PET/CT, despite ESR was altered still below the threshold of diagnosis; it also showed a new site of inflammation of the aortic vessel wall, not shown by the CE-CT.

It was found interesting that CE-CT performed one month after the end of the corticosteroid therapy, compared to the CE-CT performed at the diagnosis, showed a size reduction by $43 \%$ and a CE reduction from $48-73 \mathrm{HU}$ to
32-61 HU, while 18F-FDG-PET/CT, performed at the end of corticosteroid therapy, compared with that performed at the diagnosis, showed an increase of $18 \mathrm{~F}-\mathrm{FDG}$ uptake by $51 \%$. We have hypothesized that metabolic changes that occurs in the recurrence precede the morpho-structural ones and justify the increment of 18F-FDG uptake and the absence of CE-CT increase at the same sites.

This metabolic evidence was important in the choice of the new therapeutic strategy.

18F-FDG-PET/CT can play an important role in the diagnosis of patients with an initial clinical suspicion of retroperitoneal fibrosis, providing useful data for the differential diagnosis from other retroperitoneal diseases. It is also useful in cases of exacerbation and progression of the disease, highlighting new foci of inflammation, not documented at morphological imaging (CE-CT), helping the choice of a valid therapeutic strategy and monitoring the disease free survival.

\section{References}

1. Vivas I, Nicolás Al, Velázquez P, Elduayen B, Fernández-Villa T, Martínez-Cuesta A. Retroperitoneal fibrosis: typical and atypical manifestations. Br J Radiol 2000;73:214-222.

2. Drieskens $\mathrm{O}$, Blockmans $\mathrm{D}$, Van den Bruel A, Mortelmans L. Riedel's thyroiditis and retroperitoneal fibrosis in multifocal fibrosclerosis: positron emission tomographic findings. Clin Nucl Med 2002;27:413-415.

3. Katz R, Golijanin D, Pode D, Shapiro A. Primary and postoperative retroperitoneal fibrosis-experience with 18 cases. Urology 2002:60:780-783.

4. Vaglio A, Corradi D, Manenti L, Ferretti S, Garini G, Buzio C. Evidence of autoimmunity in chronic periaortitis: a prospective study. Am J Med 2003;114:454-462.

5. Schirmer M, Calamia KT, Wenger M, Klauser A, Salvarani C, Moncayo R. 18F-fluorodeoxyglucose-positron emission tomography: a new explorative perspective. Exp Gerontol 2003;38:463-470.

6. Nabi HA, Zubeldia JM. Clinical applications of (18)F-FDG in oncology. J Nucl Med Technol 2002;30:3-9.

7. Jansen I, Hendriksz TR, Han SH, Huiskes AW, van Bommel EF. (18) F-fluorodeoxyglucose position emission tomography (FDG-PET) for monitoring disease activity and treatment response in idiopathic retroperitoneal fibrosis. Eur J Int Med 2010;21;216-221.

8. Monev S. Idiopathic retroperitoneal fibrosis: prompt diagnosis preserves organ function. Cleve Clin J Med 2002;69:160-166.

9. Feild C, Arnold W, Gloster ES, Sharp G, Redman J. Steroid therapy as treatment for idiopathic fibrosis of the retroperitoneum and mediastinum. Pediatrics 1986;78:936-938.

10. Grotz W, von Zedtwitz I, Andre M, Schollmeyer P. Treatment of retroperitoneal fibrosis by mycophenolate mofetil and corticosteroids. Lancet 1998;352:1195.

11. Vaglio A, Palmisano A, Alberici $F$, Maggiore U, Ferretti S, Cobelli R, Ferrozzi F, Corradi D, Salvarani C, Buzio C. Prednisone versus tamoxifen in patients with idiopathic retroperitoneal fibrosis: an open-label randomised controlled trial. Lancet 2011;378:338-346.

12. Vaglio A, Versari A, Fraternali A, Ferrozzi F, Salvarani C, Buzzio C. (18)F-fluorodeoxyglucose positron emission tomography in the diagnosis and followup of idiopathic retroperitoneal fibrosis. Artrhitis Care \& Research 2005;15:122-125.

13. Lee YK, Seo JB, Kim SS, Lim TH. Thoracic periaortic fibrosis mimicking malignant tumor: CT and 18F-FDG PET findings. AJR Am J Roentgenol 2007;188:345-347. 